\title{
A Balanced Scorecard for Measuring the Impact of Industry- University Collaboration
}

\author{
Ahmed Al-Ashaab ${ }^{1}$, Myrna Flores ${ }^{2}$, Andrea Magyar ${ }^{1}$, Athanasia \\ Doultsinou $^{1}$
}

${ }^{1}$ Decision Engineering Centre, SAS, Cranfield University, United Kingdom

${ }^{2}$ CEMEX Global Center for Technology and Innovation, CEMEX Research Group AG, Römerstrasse 13 CH-2555 Brügg, Switzerland

Research and Networking, Processes and IT

$\frac{\text { a.al-ashaab@cranfield.ac.uk }}{\text { magyar.andy@gmail.com }}, \underline{\text { myrnafatima.floultsinou@ @ cranfield.ac.uk }}$,

(Received XX Month Year; final version received XX Month Year)

\begin{abstract}
The Balanced Scorecard (BSC) can be considered as a strategic measurement tool. Since its first publication by Norton and Kaplan in the early 1990's, many companies have applied it to measure four key aspects of their organisations' performance: Financial, Customer, Internal Business Process, Learning and Growth. Although it is widely used in the business arena, this original BSC was not developed to assess the impact of collaborative research projects under an open innovation strategy, where the outputs of research and development (R\&D) developed by collaborative projects undertaken by industry and universities should be measured in a different way. Therefore, this paper will propose a Scorecard to measure the outcomes of collaborative research. It is important to recall that this scorecard has been developed during a collaborative research project by CEMEX Research Group AG (Switzerland) and Cranfield University (UK). During such project, a survey was developed to carry out eleven face-to-face interviews in a sample of ten companies in UK, where it was confirmed that a collaborative balanced scorecard (CBSC) is a very useful tool to measure, track and improve the impact of conducting collaborative projects with universities. It should also be noted that this paper is an extended version of the one presented at the PRO-VE'09.
\end{abstract}

Keywords: balanced scorecard, open innovation, industry-university Collaboration

\section{Introduction}

The Balanced Scorecard (BSC) is a simple and useful measurement tool to track companies' performance [1]. It incorporates four main perspectives, namely customer, financial, internal business process and learning and growth. Only one is related to the financial measures, which is usually the main concern of firms when measuring profitability and performance. Therefore, when the BSC was initially proposed, it integrated the other three key elements to measure business success. As a result, the traditional view to only measure the financial indicators of a firm was complemented 
in the BSC to obtain the following four perspectives: 1) Financial, 2) Customer, 3) Internal Business Process, 4) Learning and Growth. The perspectives are the views of a company on particular vantage points which cover the main company activities [2]. Those perspectives need to be assessed. This is possible due to the definition of the four elements proposed by Kaplan and Norton (1996) as shown in Figure 1: Objectives, Measures, Targets and Initiatives.

The first element "objectives" focuses on clarifying and translating the company's vision into strategy. Companies need to define the aims and the achievements they want to reach in the future. This would allow the creation of a strategy that would enable them to reach their goals. The second element "measures" looks forward to communicating and linking the objectives with the results. Firms have to identify quantitative indicators for each objective. Therefore, the defined objectives and measures need to be distributed by means of newsletters, board meetings, companies' radios and electronic networks to make every employee aware of them. The third "target" element means planning and setting qualitative or quantitative goals. In other words, firms need to set numbered targets for each measured perspective. These targets may reflect the future aims in short or long term periods. The fourth and last element "initiatives" means using the strategic feedback and learning from past errors to improve. It relates to doing activities to facilitate the achievement of the targets [3].

When companies set out their future targets and plan them, they need to examine what they did during the last period in order to continuously improve. This supplies them with strategic feedback. Companies can then move forward with their business and decide for new initiatives or projects. Therefore, the BSC is used as a framework that emphasises the importance of each of the four perspectives. It helps 
translating strategy into action [4]. Unfortunately, the traditional BSC is neither appropriate nor useful to measure the innovation outcomes when implementing an open innovation model [7] when companies need to collaborate with external partners to develop new solutions [5], [6]. Therefore, this paper will present the outcomes of a collaborative research project where a novel CBSC was designed to measure the outcomes of collaborative efforts between industry and academia.

\section{A Scorecard for Open Innovation}

It is important to highlight that the original BSC [1] was developed before the current growing trends of innovation and collaboration to be competitive in the global business environment. Therefore, the four proposed perspectives considered the firm as a closed entity and did not identify as strategic the current need from companies to be leaders at product and process innovations to remain competitive. Additionally, this first scorecard did not consider the fact that many new developments would be carried out with external partners, such as universities or research institutions outside the firm boundaries.

$\mathrm{R} \& \mathrm{D}$ to achieve innovations is a very costly, risky and lengthy process. Nowadays, it is difficult and challenging for companies to innovate in short periods of time in an ever increasing global market where customer needs change quickly and the product life cycle gets shorter. Some of these concepts have been lately spread by several authors. For instance, Chesbrough [7] defines the traditional innovation process as a Closed Innovation Model. The reason is that all innovation activities are located inside the company from the ideas creation, development process, sales and marketing. In this case, companies think that they are the best in their field; they have enough knowledge and resources inside their firm boundaries to develop such new solutions. According to Viskari [8], there are four erosion factors that cause problems 
in such closed innovation model: 1) availability and mobility of skilled people, 2) venture capital market, 3) external options for ideas "sitting on the shelf" and 4) capability of external suppliers.

Therefore, the closed innovation model cannot satisfy the fast changing demands of global customers in a changing society. Chesbrough [7] defines the Open Innovation model as the use of purposive inflows and outflows of knowledge to accelerate internal innovation, and expand the markets for external use of innovation. In other words, the new value chain is the assembly of all the processes and related activities that are important from the beginning to the final customer product or service, as each of those activities add value during the process. Opening up can allow companies to tackle some issues, such as high costs involved in $\mathrm{R} \& \mathrm{D}$, lack of skilled people and lack of knowledge inside the company.

In fact, many collaboration models have emerged to achieve more innovation outputs under collaborative environments, such as virtual organisations or living labs. As this is not a trivial matter, a science should be considered where more research should be carried out to provide more tools and methodologies enabling more successful partnerships [9]. As a consequence, new models to measure collaboration outputs targeting value measurement systems have been also proposed [10].

Overall, the Open Innovation concept strongly focuses on the cooperation with others to achieve innovations, such as universities and research institutes. The main aim of the corporate innovation with universities is to generate novel solutions improving business performance and also integrating new latent needs, such as sustainability. As a result, Chesbrough [11] defined six types of business models related to two aspects: Intellectual Property (IP) management and innovation process, 
as shown in Table 1 . The adaptive business model, type 6 , emphasises the importance of the connection between the business model and the innovation process.

Companies can apply an adaptive business model and collaborate with universities on different research projects in order to be more competitive in the market. Collaborative research with universities is one of the main aspects for the development and dissemination of knowledge that helps accelerating the internal innovation process in firms [12]. The knowledge transfer between universities and companies allows the latter to survive on the rapidly changing competitive market. As a result, there is a need for a tool to help in measuring the impact of research collaboration between industry and universities. For this purpose, this paper presents a novel CBSC, which is described in detail in the following sections.

\section{CEMEX - Cranfield University Research Project Objectives}

As a result of the previously mentioned trends, there is a need to measure key elements besides the four perspectives proposed in the original BSC. Therefore, a collaborative research project between CEMEX and Cranfield University was defined and carried out to design a novel CBSC to enable companies measure the impact of collaborative projects with universities applying an Open Innovation model. Additionally, the need to assess how these collaborative projects could also impact the economic, social and environmental axis of sustainable development was highlighted. Hence, this CEMEX - Cranfield University collaborative research project had the following objectives:

(1) To obtain best practices with regards to open innovation to measure collaborative research outputs based on a detailed literature review and an industrial field study.

(2) To develop industrial case studies based on face to face interviews and a survey to design and validate a generic CBSC for Open Innovation, integrating new perspectives. 
The unit of analysis to perform the data gathering and document such case studies, as a base to design the Open Innovation Scorecard was: Industry-University collaborative research projects. Therefore, the target was to define new perspectives and measures to design the Scorecard and analyse the result of such collaborations for innovation.

\section{THE LEAD Collaborative research methodology framework}

The LEAD (Learn, Energise, Apply and Diffuse) framework developed in CEMEX to manage collaborative projects with external partners was applied as follows:

(1) LEARN

1.1 Extensive literature review to capture the state-of-the-art on Key Performance Indicators (KPIs), Scorecard and Open Innovation.

1.2 An industrial field study about industrial opinions regarding their involvement in collaborative $\mathrm{R} \& \mathrm{D}$ projects with universities.

(2) ENERGISE

2.1 Contact companies in the UK to arrange interviews and design, send and apply a structured questionnaire to obtain the lessons learned about their experiences and results when developing collaborative R\&D projects with universities. In other words, how the research results were applied for business outcomes and how they were measured in terms of qualitative and quantities performance. Hence, with the aid of the questionnaire, identify potential industrial KPIs to measure the impact of collaborative R\&D projects with Universities.

2.2 Synthesise the industrial best practices to implement collaborative R\&D outcomes and measure the performance.

2.3 Map the current literature of KPI against the industrial KPI from the questionnaire to measure the impact of collaborative research projects with universities. 
2.4 Propose a set of KPIs (measures) to be integrated in the balanced scorecard for open innovation.

(3) APPLY

3.1 Design a matrix type of CBSC for open innovation to measure the impact of research results with universities on companies' performance via the use of literature and questionnaire results.

3.2 Validate the CBSC in two different companies.

(4) DIFFUSE

4.1 Disseminate the results within industry and generic outcomes in international conferences and journals.

The aforementioned stages of the LEAD framework implementation are illustrated in Figure 2.

\section{Industrial Field Study}

During the 'energise' phase of the LEAD methodology framework, a questionnaire was designed to capture the industrial needs of collaborative $R \& D$ projects with universities. The firms' information enabled the design of the CBSC for Open Innovation. Ten British companies from different sectors participated in this study. These are (some of the companies' names are not disclosed due to confidentiality issues; hence, these are represented by the sector they belong to):

(1) Aerospace: One of the world's leading aircraft manufacturers

(2) Kodak: Multinational for its imaging innovations in cameras and printers

(3) Skill2Learn: SME doing serious business games

(4) Leading developer and manufacturer of optical solutions

(5) Smart Technology Limited: Company that manufactures and develops products based on smart materials

(6) I-I-Ice Refrigeration: Refrigeration and air conditioning

(7) SKF: Leading global supplier of products and services related to rolling bearings, seals, mechatronics and lubrication systems

(8) Aerospace: Global business providing integrated power systems for use on land, at sea and in the air

(9) Caltec: Company that designs, develops and supplies equipment for improving production from oil and gas wells.

(10) Automotive OEM. 
The main findings of the face to face interviews were [13]:

(1) Companies have different aims when applying Open Innovation models, but the most important aim is to create new technology, as shown in Figure 3.

(2) Most of the companies believe that getting intellectual capital and developing knowledge relationships are the main benefits of collaborating with universities.

(3) Another benefit was to generate more business by creating new products through the collaboration with universities.

(4) Most of the companies have always used peer review to measure research impact and have sometimes used return on investment, financial data analysis and a number of patents to measure research impact. In contrast, most of the companies have never used the BSC or any other tool to measure collaborative research impact. The most common way to measure research impact is the number of publications and the development of satisfaction surveys.

(5) The key balance pairs are: Long/Short term objectives, followed by Financial/Non-Financial measures and by Lag/Lead indicators.

(6) Most companies voted for the creation and dissemination of knowledge, employee efficiency and revenues as the three most important indicators to measure collaborative projects with universities or research institutes.

(7) Competitiveness was selected by the majority of the companies as the most important perspective for collaborative research projects with universities and/or research institutes.

\section{The Collaborative Balanced Scorecard for Open Innovation}

This section describes in detail how the CBSC (see Figure 5) was designed during the research project [13]. A graphical illustration of the steps followed is presented (Figure 4) and then, a description of each step is provided.

STEP 1: The very first step was to develop a sound understanding of the whole original concept of the BSC through literature. Norton and Kaplan [1] created the original theory of the Balanced Scorecard in 1992. Since then, a wide range of papers, articles and researches have been conducted to improve and apply the original BSC to different industrial sectors with new perspectives.

STEP 2: The second step aimed at gaining a good understanding on the Open Innovation method and how the University-Industry Collaboration process works nowadays. This led to a better understanding of what the universities, as well as the companies, gain from such collaboration. 
STEP 3: The third step was to find out what the possible inputs for the CBSC are based on the first two steps. The following inputs have been defined from the literature and stored in a matrix (see Table 2).

- what type and how many perspectives each author uses in his/her publications

- which balance pairs each author thinks the BSC can use to maintain such a balance

- how the original elements of the BSC have been modified through the literature

- the different Key Performance Indicators used by each author.

These inputs and matrices helped to get a better overview of the main concepts and define the different industrial applications that the BSC can be used for as a measurement concept. Therefore, these help to argue and identify the relevant elements for the new CBSC, which the following steps will allow to design.

STEP 4: This step aimed at gaining even more inputs for the new CBSC with the aid of the questionnaire. The questionnaire was designed in order to understand the company needs and help to build the CBSC for Open Innovation.

STEP 5: This step included the dissemination of the questionnaire to different companies, and the analysis of the obtained results.

STEP 6: Here, an initial design and layout of the CBSC was created as an example, based on the conducted literature research.

STEP 7: This final step described the final design of the CBSC.

After concluding the collaborative project with Cranfield University, based on the lessons learned of the 10 British Companies interviewed in the project, the following six BSC perspectives have been proposed and illustrated in Figure 5 as follows.

(8) Competitiveness: The ability to develop and implement new business models, tools, frameworks and methodologies for an organisation to optimise its internal working practices and business processes performance.

(9) Sustainable Development: The capacity to impact the environmental, social and economical concerns in each of the new collaborative projects with universities, integrating an organisation's key internal and external stakeholders. 
(10) Innovation: New value creation by developing new services, processes and intangible assets in a firm.

(11) Strategic Partnerships: The development of new partnerships with external organisations, such as universities, consulting companies or associations in order to develop in a collaborative way new knowledge and innovation outputs.

(12) Human Capital: The capacity to develop, share and diffuse new knowledge that can contribute to the company's growth and success.

(13) Internal Business Processes: Processes that a company requires in order to share and apply the collaborative research results during and after the conclusion of collaborative projects.

A collection of the CBSC perspectives is shown in Figure 5.

Each one of the proposed Balanced Scorecard's perspectives has objectives to achieve and there are certain relationships among them, for example creating new intellectual capital will increase new technology development in a firm. These cause and effect relationships among the objectives are shown in Figure 6. Some of the most relevant Key Performance Indicators (KPIs) as part of the "measures" element proposed to track and assess the performance of Open Innovation initiatives carried out [13] are:

(1) Competitiveness:

- Annual budget invested in collaborative R\&D

- Number of new business models or frameworks developed and implemented through collaborative projects per year to support the business and IT evolution in an organisation.

(2) Sustainable Development:

- Number of collaborative projects that improved environmentally or socially any region, community or facility

- Number of key internal and external stakeholders integrated in collaborative projects to improve sustainability concerns in the construction value chain

- Number of projects that developed new models, methods and/or standards to improve sustainability practices: health and safety, recycling methods, sustainable construction, etc

- Number of Knowledge Transfer Sessions organised to present Sustainability trends, novel technologies, etc.

(3) Innovation:

- Number of intangibles per year as a result of collaborative projects with universities, in the form of patents, licenses, copyrights, trademarks, etc.

(4) Strategic Knowledge Partnerships:

- Number of partnerships with which strategic collaborative projects are developed.

- Number of collaborative projects with universities per year

- Number of collaborative projects with consulting companies per year 
- Number of successful proposals developed collaboratively to obtain external funding, such as the European Seventh Research Framework (FP7)

- Number of projects funded by external organisations

- Number of joint publications in scientific journals or conferences.

(5) Human Capital:

- Number of new highly skilled employees per year hired in a company as a result of collaborative projects, for instance students that participated in collaborative projects (attracting new talent)

- Number of a company's employees attending Knowledge Transfer Sessions (KTS) developed during and after collaborative projects

- Number of international conferences, which employees have attended to track trends and develop new projects.

(6) Internal Business Processes:

- Number of new best practices developed and adopted in the company per year in each business process

- Number of improvements done to key End-to-End processes embedded in the CEMEX Business Process Architecture (BPA).

- Number of new tools, methodologies and methods developed to improve any internal business process to increase its efficiency as a result of a collaborative project with external partners.

The new designed CBSC includes all the above listed KPIs. Each of them is related

to a specific perspective, and can be measured to see whether a specific objective has been reached or not.

The relevant objectives identified for each perspective are as follows:

- Profitability

- Cutting costs

- Decrease the environmental footprint of the company

- Create innovative recycling methods

- Increase the number of patents

- Increase new product development

- Increase new service development

- Increase new technology development

- Knowledge dissemination

- Sharing intellectual capital (IP)

- People employment

- Learning

- Process improvement

\section{Proposed KPIs for University-Industry Collaboration (UIC)}

There was a need to collect the current KPIs and create new ones for UIC. Up to date, a common and standardised way to measure the impact of the collaborative projects between universities and industry has not been defined. Both seem to use some quite 
regular measurement tools to estimate the economic impact of the collaborative projects, such as the return on investment (ROI) or peer reviews. However, these measurement tools have not given a satisfactory overview of the results of these collaborative projects.

The following set of KPIs to measure the UIC results were defined as an outcome of the literature review and the analysed results of the questionnaires and interviews:

- Return on investment (ROI)

- Investment per year on collaborative projects with Universities

- Gross profit of the new product developed thanks to the collaborative project

- Percentage of cost savings per year thanks to University based research

- Amount of $\mathrm{CO}_{2}$ produced per year $\left(\mathrm{m}^{3}\right)$

- Percentage of recycled materials used

- Number of applied environmental friendly methods in the company per year

- Number of patents by the company per year

- Number of patents per year thanks to the collaborative project with universities

- Number of new products developed by the company per year

- Number of new products developed thanks to the collaborative project with universities per year

- Number of new services developed by the company per year

- Number of new services developed thanks to the collaborative project with universities per year

- Number of new technology developed by the company per year

- Number of new technology developed thanks to the collaborative project with universities per year

- Number of collaborative projects in the company per year

- Determine the average duration of the collaborative projects

- Number of collaborative projects with universities in the company per year

- Number of joint publications

- Number of best (business) practice case studies per year

- Number of students working with the company per year

- Number of new employees per year thanks to the collaborative project

- Number of joint training

- Work based degree (Part Time students)

- Number of successfully completed (business) projects thanks to the collaborative projects per year

$\circ \quad$ Number of best (business) practice adopted per year 


\section{The CBSC validation through two industrial case studies}

The following subsections present two different industrial case studies, which were carried out in order to validate the CBSC. The first one is with CALTEC, a smallmedium size company (where the technical director- more than 20 years of experience- was interviewed) and the second one is with an automotive OEM (where the innovation and knowledge management director- more than 15 years of experience- was interviewed) [13]. The case studies were conducted through face-toface interviews, where each card of the CBSC (Figure 5) needed to be filled sequentially. It is important to mention that although ideally all fields of the CBSC should be filled, it is possible that for various reasons (e.g. data not available, data not accurate, non-applicability to a specific company) some of them could be left without data.

\section{CALTEC case study}

CALTEC is a small-medium size enterprise serving the petrochemical sector. The company activities make it strongly involved in knowledge dissemination. CALTEC has invested significantly in Collaboration and Development in the last three years. The company supports joint venture with other companies, funds internal R\&D and university collaborations. CALTEC keep seeking for external funding to support part or all of these types of collaborative research.

The aims of the collaboration and development projects are the following:

- enter into a new market

- new technology development

- new product development

- create knowledge capital

- cutting costs

- increase market share within existing market

The company uses currently a few measurement tools to measure the research impact, but these do not give a complete view of the company's results. The main 
measurement tools are the intellectual capital index, the value creation index, the number of created jobs and the client satisfaction. Each of these measurement tools only reflects on the results of a single specific area. The company also agrees that the financial data analysis measurement tool is not enough on its own to reflect on the company's implemented research results. The company emphasised the need for a clear, customised way to measure the impact of collaborative research projects results on its performance.

The company was satisfied with the idea of the CBSC measuring the impact of collaborative research project results on its performance. It agreed with the six defined perspectives. Only a few of the objectives and perspectives were not relevant; hence, they successfully managed to fill in most of the CBSC data fields. The results are shown in Tables 3 to 8 , which represent all cards of the CBSC (each table represents one perspective).

\section{CALTEC competitiveness card}

With regards to competitivess, CALTEC has two main objectives, each of which is measured by KPIs.

(1) The first objective is profitability. The company uses three KPIs:

- The time for ROI: it is currently 2 years with a targeted value of 1 year. This can be achieved by increasing the focus of collaborative projects.

- The investment per year on collaborative projects with universities is the second KPI. It is currently 5,000 per month and the company wants to increase this value to 10,000 per month by engaging more university students.

- The last KPI is the gross profit of the new products developed thanks to the collaborative projects, which is currently 250,000 and the company aims at doubling it.

(2) The second objective is the cost reduction. The KPI used is the percentage of cost savings per year thanks to the university-based research. It is currently $20 \%$ and the future target is $25 \%$; to achieve this, more projects should be carried out.

\section{CALTEC sustainable development card}

As far as sustainable development is concerned, the company has two objectives. 
(1) To decrease the environmental footprint of the company. CALTEC uses its own KPI to measure its environmental footprint, the MMSCF (Million Standard Cubic Feet of gas) per day, instead of the amount of $\mathrm{CO}_{2}$ produced per year. The current value is 15 and they aim to double it by increasing the market size. The second KPI for this objective is the percentage of the reuse of a number of components instead of the percentage of recycled materials. The company only stated the current value of the KPI, which is $5 \%$.

(2) To create innovative recycling methods. The KPI used is the number of applied environmental-friendly methods in the company per year. Currently, the number is 3 and the aim is to double it by increasing the environmental projects.

\section{CALTEC innovation card}

Table 5 illustrates the CALTEC innovation card. As it can be seen, the company has

five objectives, each of which uses two KPIs.

(1) Increase the number of patents: The KPIs are: the number of patents in the company per year and the number of patents thanks to the collaboration with universities per year. The values are 3 and 1 respectively, and the target is to keep these values by remaining open-minded.

(2) Increase the new product development: The KPIs are: the number of new products in the company per year and the number of new products thanks to the collaboration with universities per year. The values are 6 and 2 respectively, and the target is to double the first one by increasing the number of projects, whereas they aim to keep the second one the same via a good relationship with universities.

(3) Increase the new service development: The KPIs are: the number of new services in the company per year and the number of new services thanks to the collaboration with universities per year. The value for the first KPI is 0 and they plan to increase it to 1 through the development of a new business model, whereas the second KPI was not applicable to CALTEC.

(4) Increase the new technology development: The KPIs are: the number of new technology developed in the company per year and the number of new technology thanks to the collaboration with universities per year. The values are 2 and 1 respectively, and the target is to increase the first one to 3 through idea generation, whereas they aim at keeping the second one the same via a good relationship with universities and idea generation.

\section{CALTEC partnership card}

Table 6 illustrates the CALTEC partnership card, where two main objectives can be

found. These are:

(1) Knowledge dissemination. It has three KPIs. The first one is the number of collaborative projects per year, which is currently 2 and its target value is 4 . The second KPI is to determine the average duration of the collaborative projects, which is currently 6 months and the company intends to keep this period unchanged. The third KPI the number of collaborative projects with 
universities in the company per year. The current value is 1 and the target value is 2 ; to achieve this, CALTEC has to support more students in universities.

(2) Sharing of intellectual capital. The number of joint publications and the number of best practice case studies per year are the KPIs. The first one was not applicable to CALTEC, since they have not so far shown interest in participating in joint publications. For the second one, the value is 2 and they plan to increase it to 4 by being open-minded.

\section{CALTEC human capital card}

Table 7 represents the CALTEC human capital card. There are two objectives:

(1) People employment. The first KPI is the number of students with the company per year, whose value is currently 2 and the future target value is 4 . The increase in the value can be achieved by hiring more students. The second KPI is not applicable to CALTEC.

(2) Learning. The first KPI is the number of joint training and is not applicable to CALTEC. The second KPI is the work-based degree, whose value is 1 currently and the company aims at keeping it the same by being open-minded.

\section{CALTEC internal business processes card}

Regarding the internal business processes (see Table 8), CALTEC has one objective, which is process improvement, and two KPIs to measure it. The first KPI is the number of successfully completed (business) projects thanks to the collaborative projects per year. The current value of the KPI is 2 and the future target value is set at 3, which can be achieved by being open-minded. The second KPI is the number of best business practice adopted per year, which is currently 0 , and the company aims at increasing it to 1 by conducting knowledge-oriented work.

\section{Automotive OEM case study}

The second case study was conducted in collaboration with a global OEM in the automotive sector. They have had a few experiences in collaborating with universities on research projects in the last few years.

The company's aims for working on Collaboration and Development are the following:

- new process development

- new product development

- create knowledge capital 
The company gets several benefits from the results of the collaboration on different research projects with universities. The following benefits were mentioned:

- Intellectual Capital

- Business, make profit from the implemented results

- Improve the existing products

- Keep and expand existing relationships thanks to the collaborative projects

- New process development

The company's innovation process comprises idea generation and selection, research and technology development, implementation and market introduction. The company is interested in getting support from universities in its innovation process in the following areas: implementation, ideas selection and new innovative products.

They currently use a few measurement tools to identify the research impact, but these do not give a complete view of the company's results. The main measurement tools are the ROI, peer review, number of patents and intellectual capital index. Each of these tools only reflects on the results of a single specific area. The company highlighted the necessity for a clear, customised tool to measure the impact of collaborative research projects results on its performance.

The company agreed with the idea of the CBSC measuring the impact of collaborative research projects' results on its performance and also liked the six defined perspectives. Due to time limitation and partial non-applicability, only half of the CBSC was filled and the results are displayed in the Tables 9, 10 and 11, which represent three cards of the CBSC, namely partnership, human capital and internal business processes respectively.

\section{Automotive OEM partnership card}

Table 9 illustrates the automotive OEM partnership card, where two main objectives can be found. These are:

(1) Knowledge dissemination. It has three KPIs. The first one is the number of collaborative projects per year, which is currently 1 and its target value is 3 . The second KPI is to determine the average duration of the collaborative 
projects, which is currently 1 year, and the company intends to keep this period unchanged. The third KPI the number of collaborative projects with universities in the company per year. The current value is 1 and the target value is 3 ; to achieve this, they need to increase the number of university students.

(2) Sharing of intellectual capital. The number of joint publications and the number of best practice case studies per year are the KPIs. The first one was 0 currently, and the future target value is 3 . For the second one, the value is 1 and they plan to increase it to 3 via continuous learning.

\section{Automotive OEM human capital card}

Table 10 illustrated the automotive OEM human capital card. Two objectives can be found:

(1) People employment. The first KPI is the number of students with the company per year, whose value is currently 1 and the future target value is 3 . The increase in the value can be achieved by investing in more students. The second KPI is the number of new employees per year thanks to the collaborative projects, which is currently 0 and the company aims at increasing it to 3 .

(2) Learning. The first KPI is the number of joint training and is currently 0. No information regarding the future company targets was provided. The second KPI is the work-based degree, whose value is 3 currently and the company aims at keeping it the same by providing internal and external support.

Automotive OEM internal business processes card

Table 11 is an illustration of the internal business processes card filled in by the automotive OEM. There is one objective, which is process improvement, and two KPIs to measure it. The first KPI is the number of successfully completed (business) projects thanks to the collaborative projects per year. The current value of the KPI is 1 and the future target value is set at 3 , which can be achieved by utilising the project results in business. The second KPI is the number of best business practice adopted per year, which is currently 1 , and the company aims at increasing it to 3 by being open-minded.

Overall, the validation was positive, as it revealed that there is indeed a need to measure the collaborative research projects' results with Universities and that the CBSC is well designed to do that. The validated CBSC via the industrial case studies showed that the companies are well involved in numerous collaborations with 
Universities and they would like to enhance the present degree of collaboration; the universities would also benefit from that since an increased number of students will be involved in research projects with industry.

\section{Conclusions}

A Balanced Scorecard to measure the impact of collaborative research projects was not available in the literature and is a current need for many companies to enable an open innovation model. Therefore, during this collaborative research project, a structured questionnaire was developed to obtain industrial requirements to design a novel scorecard that integrates the collaborative aspect with universities and other external partners.

Ten British companies from different sectors participated in this study. As a result, a generic collaborative scorecard (CBSC) for open innovation has been designed. The CBSC has the flexibility to customise its KPIs according to the needs of any company. It has different KPIs in six perspectives: competitiveness, sustainable development, innovation, strategic knowledge partnership, human capital and internal business processes. The CBSC has been validated successfully in two different companies to measure their open innovation research activities in collaboration with universities and other research institutes.

The presented work is based on the theoretical foundation of the scorecard and open innovation that has been carried out based on the practical approach of the LEAD research methodology framework. The presented research output is a practical collaborative scorecard (CBSC) that is easy to use and managed by any company thanks to its self-guided approach. 


\section{Acknowledgements}

The authors would like to thank all the industrial collaborators for their support in the realisation of this research project; in particular, the participants from CEMEX, CALTEC, Kodak, Skill2Learn, Smart technology Ltd, SKF and I-I-Ice refrigeration along with all the others from the UK manufacturing companies which took part in the field study and the validation of the CBSC. In addition, a special thanks to CEMEX for sponsoring this work.

\section{References}

1. Kaplan R. and Norton D.: Translating Strategy into Action: The Balanced Scorecard", Harvard Business School Press, Boston, MA (1996)

2. Balanced Scorecard Institute: Balanced Scorecard Strategic Planning \& Management Terminology http://www.balancedscorecard.org, (2008)

3. NetMBA Business Knowledge Center, The Balanced Scorecard, http://www.netmba.com/accounting/mgmt/balanced-scorecard (2009)

4. Niven P.: Balanced Scorecard step-by-step: Maximizing Performance and Maintaining Results", John Wiley \& Sons, Inc (2002)

5. Voelpel S.C, Leibold M and Eckhoff R.A: The tyranny of the Balanced Scorecard in the innovation economy, Journal of Intellectual Capital, Vol. 7 No. 1, 2006, pp. 43-60. Emerald Group Publishing Limited (2006)

6. Gama N., Mira da Silva M. and Ataíde J.: Innovation Scorecard: A Balanced Scorecard for Measuring the Value Added by Innovation: In: Cunha P.F and Maropoulos P.G (eds) Digital Enterprise Technology Perspectives and Future Challenges. Springer (2007)

7. Chesbrough H.: Open innovation: the new imperative for creating and profiting from technology. Harvard Business School Press, Boston, MA (2006a)

8. Viskari S.: Managing Technologies in Research Organization: Framework for Research Surplus Portfolio", Research Report 176, Masters Thesis, Lappeenranta University of Technology, Lappeenranta. Available in: http://www.openinnovation.eu, (2006)

9. Camarinha-Matos L. and Afsarmanesh H.: Collaborative networks: a new scientific discipline. Journal of Intelligent Manufacturing, 16, 439-452, Springer (2005)

10. Romero, D.; Galeano, N. and Molina, A.: Virtual Organisation Breeding Environments Value System and its Elements, in Journal of Intelligent Manufacturing. DOI 10.1007/s10845-008-0179-0, Springer (2007)

11. Chesbrough H.: Open Business Models, How to Thrive in the New Innovation Landscape, Harvard Business School Press, Boston, MA (2006)

12. Flores M.: Industry - University Collaboration for Innovation and Regional Development: Evidence from Madras, Monterrey, Milan and Lausanne. PhD Thesis, Politecnico di Milano (2006)

13. Magyar A.: Measuring Impact of Research Projects on Company Performance. MSc Thesis, Cranfield University (2008)

14. Flores, M., Al-Ashaab, A., and Magyar, A., (2009) A balanced scorecard for measuring the impact of industry-university collaboration, In: Leveraging knowledge for innovation in collaborative networks, $10^{\text {th }}$ IFIP WG 5.5 working conference on virtual enterprises, PRO-VE 2009, Thessaloniki, Greece, October 7-9 2009, pp 23-32

Table 1. Matrix of the Business Model Framework with the IP and innovation process (Adapted from [11])

\begin{tabular}{|l|c|c|c|c|c|c|}
\hline $\begin{array}{l}\text { Business } \\
\text { model (BM) }\end{array}$ & $\begin{array}{c}\boldsymbol{B M} \text { 1: } \\
\text { Undifferentiated }\end{array}$ & $\begin{array}{c}\boldsymbol{B M} \text { 2: } \\
\text { Differentiated }\end{array}$ & $\begin{array}{c}\boldsymbol{B M} \text { 3: } \\
\text { Segmented }\end{array}$ & $\begin{array}{c}\boldsymbol{B M ~ 4 :} \\
\text { Externally } \\
\text { aware }\end{array}$ & $\begin{array}{c}\boldsymbol{B M ~ 5 :} \\
\text { Integrated } \\
\text { innovative } \\
\text { process } \\
\text { into the BM }\end{array}$ & $\begin{array}{c}\boldsymbol{B M ~ 6 :} \\
\text { Adaptive }\end{array}$ \\
\hline $\begin{array}{l}\text { Innovation } \\
\text { process }\end{array}$ & None & Ad hoc & Planned & $\begin{array}{c}\text { Externally } \\
\text { supportive }\end{array}$ & $\begin{array}{c}\text { Connected to } \\
\text { BM }\end{array}$ & $\begin{array}{c}\text { Identifies } \\
\text { new BMs }\end{array}$ \\
\hline $\begin{array}{l}\text { IP } \\
\text { management }\end{array}$ & N/A & Reactive & Defensive & $\begin{array}{l}\text { Enabling } \\
\text { asset }\end{array}$ & $\begin{array}{l}\text { Financial } \\
\text { asset }\end{array}$ & $\begin{array}{l}\text { Strategic } \\
\text { asset }\end{array}$ \\
\hline
\end{tabular}


Table 2: Matrix of measuring perspectives

\begin{tabular}{|l|c|c|c|c|c|c|c|c|}
\hline Author & Financial & Customer & $\begin{array}{c}\text { Internal } \\
\text { Business } \\
\text { Process }\end{array}$ & $\begin{array}{c}\text { Learning } \\
\text { and } \\
\text { Growth }\end{array}$ & $\begin{array}{c}\text { Business } \\
\text { Value }\end{array}$ & $\begin{array}{c}\text { Future } \\
\text { readiness }\end{array}$ & $\begin{array}{c}\text { Internal } \\
\text { Process }\end{array}$ & Environmental \\
\hline $\begin{array}{l}\text { R. Kaplan, D. } \\
\text { Kaplan (1996) }\end{array}$ & $\mathrm{x}$ & $\mathrm{x}$ & $\mathrm{x}$ & $\mathrm{x}$ & & & & \\
\hline $\begin{array}{l}\text { M. Martinson, R. } \\
\begin{array}{l}\text { Davison, D. Tse, } \\
\text { (1999) }\end{array}\end{array}$ & & $\mathrm{x}$ & & & $\mathrm{x}$ & $\mathrm{x}$ & $\mathrm{x}$ & \\
\hline $\begin{array}{l}\text { I. Cobbold, G. } \\
\text { Lawrie, (2002) }\end{array}$ & $\mathrm{x}$ & $\mathrm{x}$ & $\mathrm{x}$ & $\mathrm{x}$ & & & & \\
\hline $\begin{array}{l}\text { R. Kaplan, D. } \\
\text { Norton, (2002) }\end{array}$ & $\mathrm{x}$ & $\mathrm{x}$ & $\mathrm{x}$ & $\mathrm{x}$ & & & & \\
\hline $\begin{array}{l}\text { E. Huerta, F. } \\
\text { Villanueva, } \\
\text { (2000) }\end{array}$ & & $\mathrm{x}$ & & & $\mathrm{x}$ & $\mathrm{x}$ & $\mathrm{x}$ & \\
\hline
\end{tabular}

Table 3: CALTEC Competitiveness card

\begin{tabular}{|c|c|c|c|c|}
\hline \multicolumn{5}{|c|}{ COMPETITIVENESS } \\
\hline OBJECTIVES & $\begin{array}{c}\text { KEY } \\
\text { PERFORMANCE } \\
\text { INDICATORS } \\
\text { (KPIs) } \\
\end{array}$ & $\begin{array}{l}\text { KPI CURRENT } \\
\text { VALUE }\end{array}$ & $\begin{array}{c}\text { FUTURE } \\
\text { TARGET VALUE }\end{array}$ & $\begin{array}{l}\text { INITIATIVES TO } \\
\text { MEET WITH } \\
\text { TARGETS }\end{array}$ \\
\hline Profitability & Time for ROI & 2 years & 1 year & To be more focused \\
\hline & \begin{tabular}{lr}
\multicolumn{2}{l}{ Investment per year } \\
on collaborative \\
projects \\
\multicolumn{2}{l}{ universities } \\
\end{tabular} & 5,000 per month & 10,000 per month & $\begin{array}{l}\text { Hire more students } \\
\text { from universities }\end{array}$ \\
\hline & $\begin{array}{l}\text { Gross profit of the } \\
\text { new product } \\
\text { developed thanks to } \\
\text { the collaborative } \\
\text { project }\end{array}$ & 250,000 & 500,000 & $\begin{array}{l}\text { Increase the profit } \\
\text { by } 10 \%\end{array}$ \\
\hline Cost reduction & $\begin{array}{l}\% \text { of cost savings } \\
\text { per year thanks to } \\
\text { university-based } \\
\text { research }\end{array}$ & $20 \%$ & $25 \%$ & $\begin{array}{l}\text { Bring more project } \\
\text { for universities }\end{array}$ \\
\hline
\end{tabular}

Table 4: CALTEC Sustainable development card

\begin{tabular}{|l|l|l|l|l|}
\hline OBJECTIVES & $\begin{array}{l}\text { KEY SUSTAINABLE DEVELOPMENT } \\
\text { PERFORMANCE } \\
\text { INDICATORS } \\
\text { (KPIs) }\end{array}$ & $\begin{array}{c}\text { KPI CURRENT } \\
\text { VALUE }\end{array}$ & $\begin{array}{l}\text { FUTURE } \\
\text { TARGET VALUE }\end{array}$ & $\begin{array}{l}\text { INITIATIVES TO } \\
\text { MEET WITH } \\
\text { TARGETS }\end{array}$ \\
\hline $\begin{array}{l}\text { Decrease } \\
\text { environmental } \\
\text { footprint of the } \\
\text { company }\end{array}$ & $\begin{array}{l}\text { MMSCF/ day of } \\
\text { gas }\end{array}$ & 15 & Double it & Increase market size \\
\hline $\begin{array}{l}\text { Create innovative } \\
\text { recycling methods }\end{array}$ & $\begin{array}{l}\% \text { reuse of some of } \\
\text { the components } \\
\text { environmental- } \\
\text { friendly methods in } \\
\text { the company per } \\
\text { year }\end{array}$ & $5 \%$ & Double it & $\begin{array}{l}\text { Increase } \\
\text { environmental } \\
\text { projects }\end{array}$ \\
\hline
\end{tabular}

Table 5: CALTEC Innovation card 


\begin{tabular}{|c|c|c|c|c|}
\hline \multicolumn{5}{|c|}{ INNOVATION } \\
\hline OBJECTIVES & $\begin{array}{c}\text { KEY } \\
\text { PERFORMANCE } \\
\text { INDICATORS } \\
\text { (KPIs) }\end{array}$ & $\begin{array}{l}\text { KPI CURRENT } \\
\text { VALUE }\end{array}$ & $\begin{array}{c}\text { FUTURE } \\
\text { TARGET VALUE }\end{array}$ & $\begin{array}{l}\text { INITIATIVES TO } \\
\text { MEET WITH } \\
\text { TARGETS }\end{array}$ \\
\hline $\begin{array}{l}\text { Increase the } \\
\text { number of patents }\end{array}$ & $\begin{array}{l}\text { Number of patents } \\
\text { by the company per } \\
\text { year }\end{array}$ & 3 & & $\begin{array}{l}\text { Keep being open- } \\
\text { minded }\end{array}$ \\
\hline & $\begin{array}{l}\text { Number of patents } \\
\text { per year thanks to } \\
\text { the collaborative } \\
\text { projects with } \\
\text { universities }\end{array}$ & 1 & 1 & $\begin{array}{l}\text { Keep being open- } \\
\text { minded }\end{array}$ \\
\hline $\begin{array}{ll}\text { Increase } & \text { new } \\
\text { product } & \\
\text { development } & \end{array}$ & $\begin{array}{l}\text { Number of new } \\
\text { products developed } \\
\text { by the company per } \\
\text { year }\end{array}$ & 6 & Double it & $\begin{array}{l}\text { Increase number of } \\
\text { projects }\end{array}$ \\
\hline & $\begin{array}{lr}\begin{array}{l}\text { Number of } \\
\text { products per }\end{array} & \text { year } \\
\text { thanks to } & \text { the } \\
\text { collaborative } & \\
\begin{array}{l}\text { projects } \\
\text { universities }\end{array} & \text { with } \\
\end{array}$ & 2 & 2 & $\begin{array}{lr}\text { Keep } & \text { good } \\
\text { relationships } & \text { with } \\
\text { universities } & \end{array}$ \\
\hline $\begin{array}{ll}\text { Increase } & \text { new } \\
\text { service } & \\
\text { development } & \end{array}$ & $\begin{array}{l}\text { Number of new } \\
\text { services developed } \\
\text { by the company per } \\
\text { year }\end{array}$ & 0 & 1 & $\begin{array}{l}\text { Develop a new } \\
\text { business model }\end{array}$ \\
\hline & $\begin{array}{lr}\text { Number of } & \text { new } \\
\text { services per } & \text { year } \\
\text { thanks to } & \text { the } \\
\text { collaborative } \\
\text { projects } \\
\begin{array}{l}\text { universities } \\
\text { with }\end{array} \\
\end{array}$ & $\mathrm{X}$ & $\mathrm{X}$ & $\mathrm{X}$ \\
\hline $\begin{array}{ll}\text { Increase } & \text { new } \\
\text { technology } & \\
\text { development } & \end{array}$ & $\begin{array}{l}\text { Number of new } \\
\text { technology } \\
\text { developed by the } \\
\text { company per year }\end{array}$ & 2 & 3 & Idea generation \\
\hline & $\begin{array}{l}\text { Number of new } \\
\text { technology per year } \\
\text { thanks to the } \\
\text { collaborative } \\
\text { projects } \\
\text { universities }\end{array}$ & 1 & 1 & \begin{tabular}{lr}
\multicolumn{3}{l}{ Idea generation and } \\
keep a good \\
relationship & with \\
universities &
\end{tabular} \\
\hline
\end{tabular}

Table 6: CALTEC Partnership card

\begin{tabular}{|c|c|c|c|c|}
\hline & & PARTNERSHIP & & \\
\hline OBJECTIVES & $\begin{array}{c}\text { KEY } \\
\text { PERFORMANCE } \\
\text { INDICATORS } \\
\text { (KPIs) }\end{array}$ & $\begin{array}{l}\text { KPI CURRENT } \\
\text { VALUE }\end{array}$ & $\begin{array}{c}\text { FUTURE } \\
\text { TARGET VALUE }\end{array}$ & $\begin{array}{l}\text { INITIATIVES TO } \\
\text { MEET WITH } \\
\text { TARGETS }\end{array}$ \\
\hline $\begin{array}{l}\text { Knowledge } \\
\text { dissemination }\end{array}$ & $\begin{array}{l}\text { Number of } \\
\text { collaborative } \\
\text { projects in the } \\
\text { company per year }\end{array}$ & 2 & 4 & $\begin{array}{ll}\begin{array}{l}\text { Business } \\
\text { corporation }\end{array} & \text { model }\end{array}$ \\
\hline & $\begin{array}{l}\text { Determine the } \\
\text { average duration of } \\
\text { the collaborative } \\
\text { projects }\end{array}$ & 6 months & 6 months & Keep this period \\
\hline & $\begin{array}{l}\text { Number } \\
\text { collaborative } \\
\text { projects with } \\
\text { universities in the } \\
\text { company per year }\end{array}$ & 1 & 2 & $\begin{array}{l}\text { Support more } \\
\text { students in the } \\
\text { universities }\end{array}$ \\
\hline $\begin{array}{l}\text { Sharing } \\
\text { intellectual capital }\end{array}$ & $\begin{array}{l}\text { Number of joint } \\
\text { publications }\end{array}$ & $\mathrm{X}$ & $\mathrm{X}$ & $\mathrm{X}$ \\
\hline & $\begin{array}{l}\text { Number of } \text { best } \\
\text { (business) practice } \\
\text { case studies per } \\
\text { year }\end{array}$ & 2 & 4 & Be open-minded \\
\hline
\end{tabular}


Table 7: CALTEC Human Capital card

\begin{tabular}{|c|c|c|c|c|}
\hline \multicolumn{5}{|c|}{ HUMAN CAPITAL } \\
\hline OBJECTIVES & $\begin{array}{c}\text { KEY } \\
\text { PERFORMANCE } \\
\text { INDICATORS } \\
\text { (KPIs) }\end{array}$ & $\begin{array}{l}\text { KPI CURRENT } \\
\text { VALUE }\end{array}$ & $\begin{array}{c}\text { FUTURE } \\
\text { TARGET VALUE }\end{array}$ & $\begin{array}{l}\text { INITIATIVES TO } \\
\text { MEET WITH } \\
\text { TARGETS }\end{array}$ \\
\hline \multirow[t]{2}{*}{$\begin{array}{l}\text { People } \\
\text { employment }\end{array}$} & $\begin{array}{l}\text { Number of students } \\
\text { working with the } \\
\text { company per year }\end{array}$ & 2 & 4 & Hire more students \\
\hline & $\begin{array}{l}\text { Number of new } \\
\text { employees per year } \\
\text { thanks to the } \\
\text { collaborative } \\
\text { projects }\end{array}$ & $\mathrm{X}$ & $\mathrm{X}$ & $\mathrm{X}$ \\
\hline \multirow[t]{2}{*}{ Learning } & $\begin{array}{l}\text { Number of joint } \\
\text { training }\end{array}$ & $\mathrm{X}$ & $\mathrm{X}$ & $\mathrm{X}$ \\
\hline & $\begin{array}{l}\text { Work-based degree } \\
\text { (part-time students) }\end{array}$ & 1 & 1 & $\begin{array}{l}\text { Keep being open- } \\
\text { minded }\end{array}$ \\
\hline
\end{tabular}

Table 8: CALTEC Internal business processes card

\begin{tabular}{|l|l|l|l|l|}
\hline OBJECTIVES & $\begin{array}{l}\text { KEY INTERNAL BUSINESS PROCESSES } \\
\text { PERFORMANCE } \\
\text { INDICATORS } \\
\text { (KPIs) }\end{array}$ & $\begin{array}{c}\text { KPI CURRENT } \\
\text { VALUE } \\
\text { TARGET VALUE }\end{array}$ & $\begin{array}{l}\text { INITIATIVES TO } \\
\text { MEET WITH } \\
\text { TARGETS }\end{array}$ \\
\hline $\begin{array}{l}\text { Process } \\
\text { improvement }\end{array}$ & $\begin{array}{l}\text { Number of } \\
\text { successfully } \\
\text { completed } \\
\text { (business) projects } \\
\text { thanks to the } \\
\text { collaborative } \\
\text { projects per year }\end{array}$ & 2 & 3 & $\begin{array}{l}\text { Keep being open- } \\
\text { minded }\end{array}$ \\
\hline & $\begin{array}{l}\text { Number of best } \\
\text { business practice } \\
\text { adopted per year }\end{array}$ & 0 & 1 & $\begin{array}{l}\text { Knowledge- } \\
\text { oriented work }\end{array}$ \\
\hline
\end{tabular}

Table 9: Automotive OEM Partnership card

\begin{tabular}{|c|c|c|c|c|}
\hline \multicolumn{5}{|c|}{ PARTNERSHIP } \\
\hline OBJECTIVES & $\begin{array}{c}\text { KEY } \\
\text { PERFORMANCE } \\
\text { INDICATORS } \\
\text { (KPIs) }\end{array}$ & $\begin{array}{c}\text { KPI CURRENT } \\
\text { VALUE }\end{array}$ & $\begin{array}{c}\text { FUTURE } \\
\text { TARGET VALUE }\end{array}$ & $\begin{array}{c}\text { INITIATIVES TO } \\
\text { MEET WITH } \\
\text { TARGETS }\end{array}$ \\
\hline \multirow[t]{3}{*}{$\begin{array}{l}\text { Knowledge } \\
\text { dissemination }\end{array}$} & $\begin{array}{l}\text { Number of } \\
\text { collaborative } \\
\text { projects in the } \\
\text { company per year }\end{array}$ & 1 & 3 & $\begin{array}{ll}\begin{array}{l}\text { Business } \\
\text { corporation }\end{array} & \text { model }\end{array}$ \\
\hline & $\begin{array}{l}\text { Determine the } \\
\text { average duration of } \\
\text { the collaborative } \\
\text { projects }\end{array}$ & 1 year & 1 year & Keep this period \\
\hline & $\begin{array}{l}\text { Number } \\
\text { collaborative } \\
\text { projects with } \\
\text { universities in the } \\
\text { company per year }\end{array}$ & 1 & 3 & $\begin{array}{l}\text { Enhance the } \\
\text { number of students } \\
\text { in the universities }\end{array}$ \\
\hline \multirow[t]{2}{*}{$\begin{array}{l}\text { Sharing } \\
\text { intellectual capital }\end{array}$} & $\begin{array}{l}\text { Number of joint } \\
\text { publications }\end{array}$ & 0 & 3 & Increase it \\
\hline & $\begin{array}{l}\text { Number of best } \\
\text { (business) practice } \\
\text { case studies per } \\
\text { year }\end{array}$ & 1 & 3 & Continuous learning \\
\hline
\end{tabular}

Table 10: Automotive OEM Human Capital card 


\begin{tabular}{|c|c|c|c|c|}
\hline \multicolumn{5}{|c|}{ HUMAN CAPITAL } \\
\hline OBJECTIVES & $\begin{array}{c}\text { KEY } \\
\text { PERFORMANCE } \\
\text { INDICATORS } \\
\text { (KPIs) }\end{array}$ & $\begin{array}{c}\text { KPI CURRENT } \\
\text { VALUE }\end{array}$ & $\begin{array}{c}\text { FUTURE } \\
\text { TARGET VALUE }\end{array}$ & $\begin{array}{l}\text { INITIATIVES TO } \\
\text { MEET WITH } \\
\text { TARGETS }\end{array}$ \\
\hline \multirow[t]{2}{*}{$\begin{array}{l}\text { People } \\
\text { employment }\end{array}$} & $\begin{array}{l}\text { Number of students } \\
\text { working with the } \\
\text { company per year }\end{array}$ & 1 & 3 & $\begin{array}{l}\text { Invest in more } \\
\text { students }\end{array}$ \\
\hline & $\begin{array}{l}\text { Number of new } \\
\text { employees per year } \\
\text { thanks to the } \\
\text { collaborative } \\
\text { projects }\end{array}$ & 0 & 3 & $\mathrm{X}$ \\
\hline \multirow[t]{2}{*}{ Learning } & $\begin{array}{l}\text { Number of joint } \\
\text { training }\end{array}$ & 0 & $\mathrm{X}$ & $\mathrm{X}$ \\
\hline & $\begin{array}{l}\text { Work-based degree } \\
\text { (part-time students) }\end{array}$ & 3 & 3 & $\begin{array}{lr}\text { Provide } & \text { support } \\
\text { (internal } & \text { and } \\
\text { external) } & \end{array}$ \\
\hline
\end{tabular}

Table 11: Automotive OEM internal business processes card

\begin{tabular}{|l|l|l|l|l|}
\hline \multicolumn{1}{|c|}{ OBJECTIVES } & $\begin{array}{l}\text { KEY INTERNAL BUSINESS PROCESSES } \\
\text { PERFORMANCE } \\
\text { INDICATORS } \\
\text { (KPIs) }\end{array}$ & $\begin{array}{c}\text { KPI CURRENT } \\
\text { VALUE } \\
\text { TARGET VALUE }\end{array}$ & $\begin{array}{l}\text { INITIATIVES TO } \\
\text { MEET WITH } \\
\text { TARGETS }\end{array}$ \\
\hline $\begin{array}{l}\text { Process } \\
\text { improvement }\end{array}$ & $\begin{array}{l}\text { Number of } \\
\text { successfully } \\
\text { completed } \\
\text { (business) projects } \\
\text { thanks to the } \\
\text { collaborative } \\
\text { projects per year }\end{array}$ & 1 & 3 & $\begin{array}{l}\text { Utilise results in } \\
\text { business }\end{array}$ \\
\hline & $\begin{array}{l}\text { Number of best } \\
\text { business practice } \\
\text { adopted per year }\end{array}$ & 1 & 3 & $\begin{array}{l}\text { Keep being open- } \\
\text { minded }\end{array}$ \\
\hline
\end{tabular}

Figure 1: The Balanced Scorecard as a Framework to translate strategy into action (Source: Norton and Kaplan [1])

Figure 2: LEAD research methodology framework

Figure 3: Key aims of the collaborative research projects with universities

Figure 4: Steps for the design of the CBSC

Figure 5: Collaborative balanced scorecard perspectives

Figure 6: Cause and effect relationships among the proposed CBSC objectives 